\title{
PENGALAMAN LANJUT USIA MENDAPATKAN DUKUNGAN KELUARGA
}

\author{
Nuurhidayat Jafar ${ }^{1,2 *}$, Wiwin Wiarsih ${ }^{3}$, Henny Permatasari ${ }^{3}$ \\ 1. Program Studi Ilmu Keperawatan Fakultas Kedokteran Universitas Hasanuddin, Makasar, Indonesia \\ 2. Program Studi Magister Fakultas Ilmu Keperawatan Universitas Indonesia, Depok 16424, Indonesia \\ 3. Fakultas Ilmu Keperawatan Universitas Indonesia, Depok 16424, Indonesia \\ *Email: yayat_vieri@yahoo.co.id
}

\begin{abstract}
Abstrak
Lanjut usia mengalami proses penuaan yang mempengaruhi fungsi fisik dan psikososial. Penelitian ini bertujuan mendapatkan gambaran pengalaman lanjut usia terhadap dukungan keluarga di panti wredha AB. Penelitian ini merupakan pendekatan kualitatif fenomenologi deskriptif menggunakan wawancara mendalam dan catatan lapangan. Alasan lansia di panti digambarkan dengan tema keinginan personal dan kelemahan struktur kekuatan keluarga. Masalah yang dialami lansia digambarkan dengan tema masalah fisik dan masalah psikososial. Dukungan yang diterima digambarkan dengan tema sumber dukungan dan jenis dukungan. Makna dukungan digambarkan dengan tema kesenangan batin. Harapan lansia digambarkan dengan tema mempertahankan hubungan. Hasil penelitian ini diharapkan menjadi dasar program promosi dan preventif bagi lanjut usia.
\end{abstract}

Kata kunci: dukungan keluarga, lanjut usia, panti wredha

\begin{abstract}
Elderly experience aging process influences physical and psychosocial functions. The aim of this research is to find description about elderly experience getting family support in AB nursing home. This research has conducted through qualitative approach using descriptive phenomenology design and was done through deep interview and field note. The aging reasons were described by themes of personal desire and weakness of family power structure. The aging problems were described by themes of physical and psychosocial problem. The supports which have received were described by themes of supporting resource and kind of support. The meaning of support was described by internal happiness. The aging hope was described by theme of defend relationship. The result of this research is expected to be able to become the foundation of promotion and prevention programs for elderly.
\end{abstract}

Keywords: elderly, family support, nursing home

\section{Pendahuluan}

Keberhasilan pembangunan kesehatan ditandai dengan meningkatnya beberapa aspek, seperti kualitas sumber daya manusia, kualitas hidup, kesejahteraan keluarga dan masyarakat, serta usia harapan hidup (Depkes RI, 2006). Salah satu yang menjadi perhatian ialah meningkatnya usia harapan hidup masyarakat yang akan berdampak pada peningkatan jumlah lansia. Lansia adalah individu berumur 65 tahun ke atas, dengan umur $65-74$ tahun disebut young-old dan umur 75 tahun lebih disebut old-old (Smeltzer \& Bare, 2001).

Laporan dari BKKBN (1999, dalam Probosuseno, 2007) pada 1995 patokan lansia 7\% di tiap wilayah melonjak, seperti DIY (12,5\%), Jawa Timur $(9,46 \%)$, Bali (8,93\%), Jawa Tengah $(8,8 \%)$, dan
Sumatera Barat (7,98\%); data ini yang digunakan untuk memperkirakan kenaikan jumlah lansia beberapa tahun ke depan. Peningkatan jumlah lansia di Indonesia tentunya perlu mendapat perhatian yang serius dari pemerintah berkaitan dengan pelayanan sosial dan pelayanan kesehatan terkait dengan proses menua. Lansia membutuhkan perhatian khusus dalam kesehatan, kemandirian, perawatan, dan penghargaan.

Alasan lansia membutuhkan perhatian khusus dikarenakan masalah pada lansia dimasukkan ke dalam "Empat Besar" penderitaan geriatrik yaitu mempunyai masalah yang kompleks, tidak ada pengobatan sederhana, penurunan kemandirian, dan membutuhkan bantuan orang lain dalam perawatan (Isaac, 1981 dalam Watson, 2003). 
Perhatian yang diberikan kepada lansia dapat berupa dukungan sosial khususnya keluarga atau kerabat dekat. Gottlieb (1983, dalam Mundiharno, 2010) menyatakan bahwa dukungan keluarga dapat merupakan informasi verbal maupun nonverbal, saran, bantuan, atau tingkah laku yang diberikan oleh orang-orang terdekat berupa kehadiran serta hal-hal yang dapat memberi keuntungan emosional kepada penerimanya.

Dukungan dari keluarga terhadap lansia sangat dipengaruhi oleh modernisasi yang menyebabkan terjadinya pergeseran nilai-nilai keluarga dalam merawat lansia. Mundiharno (2010) menyatakan ada tiga penyebab yaitu perubahan keluarga dari extended family ke nuclear family, meningkatnya tingkat partisipasi angkatan kerja pada wanita, dan migrasi keluar pada usia muda (Young-Out Migration).

Perubahan tanggung jawab keluarga mengurus lansia disebabkan keluarga yang sangat sibuk dengan pekerjaannya sehingga tidak mempunyai waktu mengurus lansia atau bahkan ditinggal sendiri oleh keluarga yang membuat hidup lansia tidak potensial dan menjadi terlantar. Kondisi ini yang menyebabkan keluarga memilih pelayanan institusi untuk mengurus lansia. Salah satu dari pelayanan institusi lansia adalah panti sosial.

Program pelayananan yang dilakukan oleh Panti Sosial Tresna Wredha (PSTW) terkait dengan peningkatan kesejahteraan lansia tidak selalu berjalan optimal. Faktor yang dapat mempengaruhi yaitu seperti terbatasnya waktu lansia mengikuti kegiatan, masih terbatas peralatan, masih tersebar beberapa fasilitas kegiatan, kurangnya SDM di panti dalam menjalankan program, keterbatasan dana khususnya membiayai instruktur dari luar (Depsos RI, 2009).

Program PSTW yang tidak optimal ditambah kurang dukungan keluarga dapat menimbulkan masalah yang dialami oleh lansia selama hidup di PSTW, terutama dalam masalah psikososial. Permasalahan psikososial yang dialami lansia terkait dukungan keluarga akan memunculkan makna dan harapan yang berbeda. Berdasarkan hal ini, maka perlu dilakukan penelitian kualitatif dengan desain fenomenologi deskriptif untuk mengidentifikasi pengalaman lansia mendapatkan dukungan keluarga dengan rumusan pertanyaan penelitian yaitu: Bagaimana pengalaman lanjut usia mendapatkan dukungan keluarga di Panti Wredha AB, Provinsi D.I. Yogyakarta.

\section{Metode}

Penelitian ini menggunakan metode penelitian kualitatif melalui pendekatan fenomenologi deskriptif. Pendekatan kualitatif ini dipilih karena peneliti ingin mendapatkan gambaran yang mendalam mengenai pengalaman lansia mendapat dukungan keluarga di Panti Wredha AB, Provinsi D.I. Yogyakarta.

Penentuan partisipan dalam penelitian ini dilakukan secara purposif dan mencapai saturasi pada partisipan ke-7 dengan kriteria inklusi lansia yang masih memiliki keluarga, lansia yang berumur 60 tahun ke atas, lansia yang mampu berkomunikasi verbal dan menceritakan pengalaman tentang dukungan keluarga. Kriteria yang lain adalah lansia yang memiliki fungsi pendengaran yang baik, lansia dapat berkomunikasi dengan menggunakan bahasa Indonesia, dan lansia setuju berpartisipasi dalam penelitian.

Pengambilan data dilaksanakan pada April sampi Juni 2010. Peneliti menerapkan prinsip etik dalam melakukan penelitian ini berdasarkan Beauchamp dan Childress (1994) yang menyebutkan ada tiga prinsip etik yang dipakai dalam penelitian kualitatif yaitu autonomy, beneficence, dan justice.

Pengumpulan data dilakukan melalui pedoman wawancara, catatan lapangan (field notes), dan MP4. Tahapan analisis data pada penelitian dengan menggunakan langkah Stevick-Colaizzi-Keen (Creswell, 1998). Trustworthiness of data (uji keabsahan data) dalam penelitian ini yaitu meliputi kredibilitas (credibility), kebergantungan (dependability), kepastian (confirmability), dan keteralihan (transferability). 


\section{Hasil}

Partisipan dalam penelitian ini berjumlah tujuh orang lansia yang tinggal di panti. Lima partisipan berjenis kelamin perempuan dan dua partisipan lainnya berjenis kelamin laki-laki. Usia partisipan beragam dalam rentang umur 61 sampai 78 tahun. Riwayat pekerjaan partisipan sebelum tinggal di panti yaitu penjahit, baby sitter, dan buruh. Tingkat pendidikan partisipan juga berbeda mulai dari tidak tamat Sekolah Dasar (SD) atau Sekolah Rakyat (SR) sampai kepada tidak tamat Sekolah Menengah Kejuruan (SMK). Jenis kepercayaan atau agama partisipan terdiri atas Islam, Kristen Protestan, dan Katolik. Semua partisipan dalam penelitian ini merupakan suku Jawa dimana lima partisipan berasal dari Yogyakarta dan dua lainnya berasal dari Semarang.

Tema-tema yang teridentifikasi dalam penelitian ini ada 8 tema yang menjawab tujuan khusus terkait dengan pengalaman lanjut usia mendapatkan dukungan keluarga. Alasan lansia tinggal di panti digambarkan dengan tema keinginan personal dan kelemahan struktur kekuatan keluarga. Keinginan personal tergambarkan dalam sub tema keinginan untuk mandiri, keikhlasan menerima kondisi hidup, dan ketersediaan jaminan sosial atau kehidupan untuk lansia dari pemerintah.

Kelemahan struktur keluarga tergambarkan dalam sub tema konflik dalam keluarga. Masalah yang dialami lansia selama di panti digambarkan dengan tema masalah fisik dan masalah psikososial. Masalah fisik tergambarkan dalam sub tema masalah sistem muskuloskeletal, masalah sistem kardiorespiratorik, masalah sistem sensoris, dan masalah pola tidur.

Masalah psikososial tergambarkan dalam sub tema masalah psikologi, masalah sosial atau hubungan dengan orang lain, dan penyebab dari masalah psikososial. Dukungan yang diterima oleh lansia selama di panti digambarkan dengan tema sumber dukungan dan jenis dukungan. Sumber dukungan tergambarkan ke dalam sub tema keluarga, panti, dan orang lain.
Jenis dukungan tergambar dalam sub tema integrasi sosial, dukungan emosional, dukungan materi, dukungan informasi, serta dukungan layanan. Makna dukungan keluarga bagi lansia digambar dengan tema kesenangan batin dengan sub tema dukungan memberikan makna positif. Harapan lansia digambarkan dengan tema mempertahankan hubungan dengan sub tema melakukan interaksi teratur, memberikan penghargaan terhadap lansia, dan mempersiapkan dan mengantar lansia ke peristirahatan terakhir.

\section{Pembahasan}

\section{Alasan Lansia Tinggal di Panti}

Lansia yang memilih tinggal di panti memiliki alasan yang beragam terutama lansia perempuan yang jumlahnya lebih banyak. Harker (1997) menyatakan bahwa salah satu alasan lansia tinggal di panti karena keinginan mereka sendiri yang mencari kebebasan serta karena kemiskinan. Lansia mencari kebebasan karena tidak ingin terikat dengan kehidupan keluarga, selain dikarenakan kemiskinan. Alasan lansia ini karena tidak ingin terlalu terikat dengan aturan dalam keluarga. Lansia menginginkan aktualisasi diri yang lebih tinggi.

Lansia tinggal di panti yang ditemukan peneliti sedikit berbeda dengan Harker yaitu dengan alasan tidak ingin membebani keluarga. Lansia memilih tinggal di panti karena tidak ingin membebani apabila secara terus menerus lansia tinggal bersama dengan keluarga baik anak ataupun saudara. Lansia juga mendapatkan kebebasan dari keluarga untuk menentukan kehidupannya termasuk keinginan untuk mandiri.

Hal tersebut sesuai dengan penelitian kualitatif. Subekti (2007) menjelaskan bahwa tinggal di panti merupakan nilai-nilai yang dimiliki oleh partisipan dan merupakan salah satu tujuan tinggal di panti wredha diantaranya karena tidak mau merepotkan anak dan membebani anak. Keinginan lansia untuk mandiri ditunjang oleh penelitian Suriadi (1999) dimana lansia yang sudah tidak bekerja lagi tetap berusaha untuk mandiri. 
Berdasarkan hasil penelitian oleh Suriadi, dari 61 responden terdapat 17 lansia $(27,9 \%)$ yang masih menjadi tanggungan keluarga, 44 lansia $(72,1 \%)$ yang sudah tidak menjadi tanggungan keluarga. Hal ini menunjukkan bahwa meskipun tidak memiliki pekerjaan utama, namun lansia tetap berkeinginan untuk mandiri dan tidak membebani keluarga.

Salah satu alasan lansia tinggal di panti wredha dalam penelitian ini adalah keluarga. Lansia lebih memilih tinggal di panti wredha karena adanya konflik dengan saudara, anak, atau cucu. Bessi (2007, dalam Mantra, 2010) menyatakan alasan lansia yang menjadi warga panti wredha Wana Seraya Bali karena kemiskinan, tidak memiliki keluarga, atau diterlantarkan oleh keluarga.

Lansia dalam penelitian ini memiliki latar belakang yang sama karena awalnya memiliki konflik dengan keluarga yang menyebabkan perpisahan dengan keluarga inti. Konflik yang terjadi berupa perselingkuhan atau perceraian yang menyebabkan lansia hidup sendiri atau bahkan terlantar. Lansia perempuan yang tidak dapat mencari penghasilan tetap mengalami kemiskinan dan memilih tinggal di panti.

Penelitian ini teridentifikasi bahwa konflik yang terjadi terdiri atas perpisahan dengan keluarga inti dan lansia yang merasa diabaikan. Depsos RI (2008) menjelaskan bahwa pergeseran nilai di tengah modernisasi dan kuatnya tuntutan secara materiil terasa semakin kuat, sehingga nilai-nilai kebersamaan, kegotong-royongan, dan tanggung jawab sosial semakin terkikis. Seseorang akan menjadi lebih individualis dan tidak lagi memiliki beban moral dan tanggung jawab sosial terhadap keterlantaran yang dialami oleh kerabat yang lain.

\section{Masalah yang Dialami Lansia Selama di Panti}

Masalah fisik terhadap lansia dapat diakibatkan oleh proses penuaan yang terjadi dan menyebabkan lamanya perawatan di panti. Menurut Gallo, Reichel, dan Andersen (1998), lansia merupakan subjek-subjek yang rentan terhadap besarnya stresor kehidupan. Lansia merupakan populasi at risk yang rentan mengalami suatu penyakit. Potter (1997) menggambarkan hampir sebanyak $80 \%$ dewasa di atas usia 65 tahun mempunyai sedikitnya satu masalah kesehatan kronis. Laporan dari WHO Technical Report Series No.919 (2003, dalam Isbagio, 2006), yang menjelaskan bahwa masalah muskuloskeletal dan penyakit rematik merupakan penyebab utama yang dapat menyebabkan angka kesakitan (morbiditas) pada lansia di seluruh penjuru dunia sehingga akan mempengaruhi kualitas kehidupan lansia yang mengakibatkan tingginya biaya pengobatan. Potter (1997) menjelaskan bahwa hampir 44\% lansia mengalami artritis dan umumnya terjadi pada wanita dibandingkan dengan pria.

Stanley, Blair, dan Beare (2005) mengidentifikasi bahwa seiring pertambahan usia, jantung dan pembuluh darah mengalami perubahan baik secara struktural maupun fungsional dan merupakan penyebab utama kematian serta disabilitas lansia di Amerika Serikat. Potter (1997) menjelaskan bahwa lansia biasanya mengalami perubahan pada indera penglihatan, pendengaran, pengecapan, dan penciuman oleh karena penuaan yang normal. Perubahan pada sistem sensoris baik penglihatan maupun pendengaran dapat berpengaruh terhadap aktivitas sosial.

Menurut Stanley, Blair, dan Beare (2005) persepsi sensoris mempengaruhi kemampuan seseorang untuk saling berhubungan dengan orang lain dan untuk memelihara atau membentuk hubungan yang baru. Lansia menjadi enggan keluar ruangan karena kurang dapat mengenali ruangan atau respon selama percakapan kurang sesuai.

National Institute of Health (1990, dalam Stanley, Blair, \& Beare, 2005) menjelaskan bahwa sebagian besar lansia berisiko tinggi untuk mengalami gangguan tidur akibat berbagai faktor. Gangguan tidur dialami oleh $50 \%$ orang yang berusia 65 tahun atau lebih yang tinggal di rumah, dan $66 \%$ orang yang tinggal di fasilitas perawatan jangka panjang termasuk panti. Masalah tidur yang dialami mempengaruhi kualitas hidup lansia. 
Menurut Havighurst (1952, dalam Stanley, Blair, $\&$ Beare, 2005), lansia masih memiliki pengalaman dan situasi baru di depan mereka untuk dihadapi. Selama tahap terakhir menjadi lansia, kemungkinan menghadapi situasi baru sangat mungkin terjadi yang dapat mempengaruhi aspek psikologi lansia.

Penelitian kuantitatif yang dilakukan oleh Nurdin (2008) tentang hubungan perubahan psikososial lansia dan perpisahan keluarga dengan tingkat kecemasan lansia di Panti Wredha Pucang Gading Semarang menunjukkan dari 63 responden, 26 responden $(41,3 \%)$ mengalami kecemasan sedang dan 17 responden (27\%) mengalami kecemasan berat. Perasaan kehilangan dan ketidakberdayaan biasanya dialami lansia secara bersamaan. Masalah ini banyak dialami lansia terutama di panti. Stanley, Blair, dan Beare (2005) menjelaskan bahwa kehilangan dapat dialami secara akut oleh lansia. Lansia di panti menghadapi banyak stresor dan merupakan salah satu resiko terkena depresi.

Blazer (1989, dalam Stanley, Blair, \& Beare, 2005) menjelaskan angka depresi meningkat secara drastis di antara lansia yang berada di institusi yaitu sekitar 50\% - 75\% penghuni perawatan jangka panjang memiliki gejala depresi ringan sampai sedang. Depresi dapat menyebabkan kemunduran fisik sehingga perlu penanganan yang tepat.

Lansia banyak yang mengalami kepribadian tertutup sehingga berakibat lansia berperilaku menarik diri seiring dengan pertambahan usia dan dipengaruhi oleh tipe isolasi sosial. Potter (1997) menjelaskan bahwa beberapa lansia dipengaruhi oleh keempat tipe isolasi sosial yaitu isolasi sikap, isolasi penampilan, isolasi perilaku, dan isolasi geografi. Lansia dalam penelitian ini dipengaruhi oleh tipe isolasi perilaku yang diakibatkan oleh perilaku yang tidak dapat diterima secara sehingga sosial menyebabkan seseorang menarik diri.

Kemampuan berespon terhadap masalah di panti menjadi penyebab masalah psikososial. Subekti (2007) menyatakan bahwa perasaan lansia saat pertama kali masuk di panti wredha yaitu berupa kesiapan tinggal di panti menunjukkan partisipan ada yang mampu menyesuaikan diri dan perasaan belum siap tinggal di panti yang disebabkan oleh kesulitan menyesuaikan diri suasana rumah dengan panti wredha.

Folkman dan Lazarus (1984, dalam Nursasi \& Fitriyani, 2002) mengidentifikasi jenis strategi koping yang digunakan oleh lansia yaitu koping yang berorientasi pada upaya penyelesaian masalah dan koping yang berfokus pada aspek emosional. Lansia mengalami kemampuan berespon yang berbeda-beda tergantung dengan tingkat stresor yang dialami lansia. Lingkungan dimana lansia itu berada dan beraktivitas sangat mempengaruhi kemampuan adaptasi dan koping dari lansia.

\section{Dukungan Keluarga yang Diterima Lansia Selama di Panti}

Keberadaan lansia dalam keluarga dapat mempengaruhi fungsi keluarga yang selanjutnya turut menentukan kemampuan keluarga untuk mendukung pencapaian kualitas hidup lansia semaksimal mungkin. Pergeseran pola masyarakat dari masyarakat agraris ke masyarakat industri atau menjadi masyarakat yang semakin maju turut mempengaruhi nilai norma keluarga, khususnya keluarga dengan lansia. Semakin banyaknya suami istri yang bekerja di luar rumah menjadi salah satu alasan perubahan nilai keluarga dalam memberikan dukungan terhadap lansia (Kersten \& Kersten, 1988 dalam Hamid \& Dibah, 1997).

Menurut Stanley, Blair dan Beare (2005) sumber pendukung pertama biasanya merupakan anggota keluarga seperti pasangan, anak-anak, saudara kandung atau cucu. Namun struktur keluarga akan berubah jika ada anggota keluarga yang meninggal atau pindah ke daerah lain. Oleh karena itu, kelompok pendukung yang lain sangat penting seperti tetangga, teman dekat, kolega sebelumnya dari tempat kerja atau organisasi lansia. Gallo, Reichel, dan Andersen (1998) menjelaskan bahwa sumber pendukung bagi lansia terdiri dari tiga komponen yaitu sumber dukungan informal, sumber dukungan formal, dan sumber dukungan semiformal. 
Setiti (2007) menjelaskan bahwa secara umum pelayanan atau dukungan kepada lansia dilakukan oleh kerabat yang paling dekat. Lansia dirawat oleh kerabat atas hubungan perkawinan atau adopsi. Pelayanan kepada lansia dilakukan oleh anak, kemenakan, saudara sepupu atau tetangga/kerabat jauh. Hasil penelitian Suriadi (1999) menemukan dari 131 lansia, 84 lansia $(64,1 \%)$ yang menyatakan sering mendapatkan bantuan dari anaknya yang telah menikah dan 47 lansia (35,9\%) menyatakan tidak pernah mendapat bantuan dari anaknya yang telah menikah.

Suriadi (1999) menjelaskan lansia yang berada di rumah sendiri berhubungan dengan saudara dalam berbagai bentuk. Penelitian yang dilakukan Suriadi pada 133 lansia, 125 lansia (94\%) mengatakan saling kunjung dan 8 lansia (6\%) yang mengatakan tidak saling kunjung. Bentuk hubungan lainnya 115 lansia $(86,5 \%)$ yang saling bertegur sapa, dan 18 lansia $(13,5 \%)$ yang tidak bertegur sapa. Penelitian yang dilakukan Setiti (2007) menyebutkan bahwa lansia membutuhkan kebutuhan psikis diantaranya yaitu dukungan emosional dimana lansia butuh lingkungan yang mengerti dan memahami mereka. Lansia membutuhkan teman untuk bicara, sering dikunjungi, dan sering disapa.

Lansia juga butuh rekreasi dan silaturahmi dari kerabat. Kebutuhan lansia yang mempengaruhi emosional lansia adalah kebutuhan sosial. Tang (2004) menyatakan bahwa kualitas dan kuantitas dukungan sosial sangat mempengaruhi perasaan lansia dari kesepian sehingga keluarga perlu memberikan informasi dengan melatih komunikasi yang baik. Informasi yang dapat diberikan sesuai dengan apa yang dianggap baik oleh lansia.

\section{Makna Dukungan Keluarga Bagi Lansia}

Partisipan merasakan kesenangan lebih jika keluarga mendukung di panti dengan melakukan kunjungan. Lansia merasakan kesenangan tersebut karena mempunyai keterikatan yang besar dengan keluarga. Erickson (1986, dalam Stanley, Blair, \& Beare, 2005) keterikatan lansia muncul karena pengalaman merawat anak dan cucu sehingga memberi rasa kedekatan pada lansia. Pengalaman merawat anggota keluarga memunculkan nilai lansia untuk diperhatikan oleh anggota keluarga tersebut.

Hasil penelitian kualitatif Ribeiro dan Paul (2008) mengenai aspek positif perawatan bagi lansia lakilaki menunjukkan adanya kepuasan dan merasa diperhatikan. Lansia mendapatkan perasaan positif selama mendapatkan perawatan dan hubungan yang sangat kuat dengan pemberi perawatan terutama dalam garis perkawinan.

Koren dan Lowenstein (2008) dalam penelitiannya menemukan makna kehidupan pada status perkawinan lansia yaitu memperhatikan kesehatan, pendidikan, kualitas dukungan sosial, dan aktivitas. Makna kehidupan bagi lansia di panti antara lain membutuhkan dukungan sosial sebagai sesuatu yang dapat membuat senang dirinya dengan memenuhi kebutuhan hidupnya. Partisipan di panti memaknai pemenuhan kebutuhan hidup tidak harus dengan pemberian materi. Masih banyak dukungan yang dapat membuat partisipan menjadi senang selain materi seperti perhatian, nasehat, empati, dan simpati.

\section{Harapan Lansia terhadap Dukungan Keluarga}

Mempertahankan hubungan dengan interaksi teratur diharapkan oleh lansia di panti. Interaksi secara teratur dapat berupa kunjungan oleh keluarga ke panti, rasa kedekatan, perasaan rindu. Weisman (1979, dalam Stanley, Blair, \& Beare, 2005) menjelaskan bahwa harapan, rasa percaya, dan kualitas hidup merupakan unsur koping produktif yang saling terkait. Harapan adalah sikap yang tidak dapat diraba yang dirancang untuk membantu seseorang melewati rintangan.

Penelitian yang dilakukan oleh Hamid dan Dibah (1997) mengenai "Perbedaan Persepsi Harapan Antara Keluarga dan Lansia tentang Pemenuhan Kebutuhan Lansia Selama Tinggal Bersama", menunjukkan bahwa adanya perbedaan persepsi antara harapan keluarga dengan lansia untuk semua kebutuhan kecuali kebutuhan spiritual. 
Perbedaan harapan lansia dengan keluarga yang paling jelas adalah pemenuhan kebutuhan terkait kebutuhan biologis. Dalam penelitian tersebut, diperoleh perbedaan dimana lansia menguraikan harapan yang sangat besar terhadap keluarga untuk memenuhi kebutuhannya terutama kebutuhan biologis. Sedangkan keluarga justru mengharapkan untuk tidak memenuhi kebutuhan biologis lansia karena ketidakmampuan ekonomi.

Setiti (2007) meneliti tentang harapan lansia kepada kerabat terdekat dan diperoleh hasil lansia menginginkan adanya pelayanan atau dukungan dari keluarga dan kerabat terdekat secara ikhlas dan wajar. Kerabat masih mendengarkan dan menjalani nasihat lansia dan bila ada perbedaan disampaikan dengan baik tanpa menyinggung perasaan. Harapan lansia yang lain dalam proses menjelang ajal perlu direspon oleh keluarga ataupun pihak panti. Hal ini penting untuk melindungi lansia dari kecemasan dan ketakutan.

Keluarga perlu berdiskusi dan memberi dukungan dalam persiapan menjelang ajal sementara perawat di panti perlu melihat tahapan yang dijalani lansia dalam menghadapi kematian. Lamberton (1973, dalam Stanley, Blair, \& Beare, 2005) menyatakan dukungan yang konsisten dari pemberi perawatan diperlukan pada saat lansia menjelang ajal karena pikiran yang tidak menentu dari lansia antara berbagai bentuk ketergantungan atau kecukupan diri.

\section{Kesimpulan}

Pengalaman lansia mendapat dukungan keluarga di panti wredha berbeda-beda. Hal ini dipengaruhi oleh banyak faktor diantaranya pergeseran nilainilai keluarga akibat modernisasi, kurangnya pengembangan program di panti, kurang perhatian dari pemerintah dalam keterlibatan program dukungan keluarga di panti. Perbedaan pengalaman lansia di panti yaitu terkait dengan alasan tinggal di panti dapat berupa keinginan sendiri ataupun karena kelemahan struktur keluarga. Masalah yang dialami lansia selama di panti beragam mulai dari masalah fisik sampai masalah psikososial.
Masalah lansia di panti belum diidentifikasi secara optimal sehingga mempengaruhi dalam melakukan aktivitas sehari-hari.

Dukungan yang diterima lansia berbeda-beda baik sumber maupun jenis dukungannya. Sumber dukungan bagi lansia bukan hanya berasal dari keluarga namun dapat berasal dari panti dan orang lain seperti siswa atau mahasiswa, aparat pemerintah, serta organisasi masyarakat yang peduli terhadap lansia di panti. Makna dukungan keluarga bagi lansia dianggap hal yang positif yang dapat memberikan kesenangan batin. Hal ini menimbulkan harapan lansia selama di panti wredha terhadap dukungan keluarga antara lain mempertahankan hubungan selama di panti (NM, $\mathrm{NN}, \mathrm{KN}$ ).

\section{Referensi}

Beauchamp, T.L., \& Childress, J.F. (1994). Principles of biomedical ethics (4th Ed.). New York: Oxford University Press.

Creswell, J. W. (1998). Qualitative inquiry and research design: Choosing among five traditions. USA: Sage Publications, Inc.

Depkes RI. (2006). Pedoman kegiatan perawat kesehatan masyarakat di puskesmas. Jakarta: Direktorat Bina Pelayanan Keperawatan Depkes, Departemen Komunikasi dan Informatika.

Depsos RI. (2008). Penguatan eksistensi panti werdha di tengah pergeseran budaya dan keluarga. Diperoleh dari http://www.depsos.go.id/modules. php? name $=$ News $\&$ file $=$ print $\&$ sid $=704$.

Depsos RI. (2009). Day care services PSTW Budhi Dharma Bekasi. Diperoleh dari www.yanrehsos. depsos.go.id/modules.php?name.

Gallo, J.J., Reichel, W., \& Andersen, L.M. (1998). Buku Saku Gerontologi. Jakarta: EGC.

Hamid, A.Y., \& Dibah, R. (1997). Perbedaan persepsi harapan antara keluarga dan lansia tentang pemenuhan kebutuhan lansia selama tinggal bersama. Jurnal Keperawatan Indonesia, 1 (2), 39-44. 
Harker, J. (1997). Help me: Coping with the nursing home decision. Diperoleh dari http://www. alharris.com/harker/helpme.htm.

Isbagio. (2006). Osteoartritis dan osteoporosis sebagai masalah muskuloskeletal utama warga usia lanjut di Abad. Diperoleh dari http://www.majalah farmacia.com/rubrik/one_news.asp? IDNews=28.

Koren, C., \& Lowenstein, A. (2008). Late life widowhood and meaning in life. Diperoleh dari http://proquest.umi.com/pqdweb?index $=0 \&$ did $=2028642941 \&$ SrchMode $=1 \& \operatorname{sid}=1 \&$ $\mathrm{Fmt}=6 \&$ VInst $=$ PROD $\&$ VType $=\mathrm{PQD} \& \mathrm{RQT}=$ $309 \&$ VName $=P Q D \& T S=1278762383 \&$ client $\mathrm{Id}=45625$.

Mantra. (2010). Panti Jompo, tempat membuang mereka yang renta. Diperoleh dari http://www. balebengong.net/kabaranyar/2010/02/07/ panti-jompo-tempatmembuang-mereka-yangrenta.html.

Mundiharno. (2010). Penduduk lansia: Perlunya perhatian terhadap kondisi lokal dan peran keluarga. Diperoleh dari www.akademika.or.id/ arsip/AGE-DSOS.PDF.

Nurdin, S. (2008). Hubungan perubahan psikososial lanjut usia dan perpisahan keluarga dengan tingkat kecemasan lansia di Panti Wredha Pucang Gading Semarang (Tesis, Program Studi Ilmu Keperawatan Fakultas Ilmu Keperawatan dan Kesehatan). Universitas Muhammadiyah Semarang, Jawa Tengah.

Nursasi, A.Y., \& Fitriyani, P. (2002). Koping lanjut usia terhadap penurunan fungsi gerak di Kelurahan Cipinang Muara Kecamatan Jatinegara Jakarta Timur. Diperoleh dari www://repository.ui.ac. $\mathrm{id} /$ contents/koleksi/2/09b860dc26e53e296c73631 cbc0c166a007c9717.pdf.

Potter, P. A. (1997). Fundamental of nursing: Concepts, process, and practice (4th Ed). St. Louis, Missouri: Mosby-Year Book Inc.

Probosuseno. (2007). Mengatasi isolation pada lanjut usia. Diperoleh dari http://medicalzone. org/fuldfk/viewtopic.php $? \mathrm{t}=3686 \& \mathrm{sid}=8 \mathrm{fb}$ 3b45481147f 18569b69466b887e37.
Ribeiro, O., \& Paul, C. (2008). Older male carers and the positive aspects of care. Diperoleh dari http://proquest.umi. compqdweb? index $=1 \&$ did $=1601688161 \&$ SrchMode $=1 \&$ sid $=1 \& \mathrm{Fmt}=6$ $\&$ VInst $=$ PROD $\&$ VType $=$ PQD $\&$ RQT $=309 \& V$ Name $=P Q D \& T S=1278762383 \&$ clientId $=$ 45625.

Setiti, S. G. (2007). Pelayanan lanjut usia berbasis kekerabatan (Studi kasus pada lima wilayah di Indonesia). Diperoleh dari www.ditppk.depsos. go.id/unduh06_PELAYANAN\%20LAN JUT\%20USIA\%20BERBASIS\%20KEKERABAT AN. pdf.

Smeltzer, S. C., \& Bare, B. G. (2001). Brunner and Suddarth's textbook of medical surgical nursing (8th Ed). Philadelphia: Lippincott-Raven Publishers.

Stanley, M., Blair, K.A., Beare, P.G. (2005). Gerontological nursing: Promoting successful aging with older adults (3rd Ed). Philadelphia: F.A. Davis Company.

Subekti, I. (2007). Pengalaman tiga bulan pertama usia lanjut tinggal di Panti Werdha Griya Asih Lawang, Jawa Timur: Studi fenomenologi (Tesis, tidak dipublikasikan). Program Magister Ilmu Keperawatan Fakultas Ilmu Keperawatan Universitas Indonesia, Depok.

Suriadi, A. (1999). Preferensi tempat tinggal pada masa lanjut usia (Studi pola pelayanan dan perawatan pada masa lanjut usia di Kotamadya Medan) (Tesis master, Program Magister IlmuIlmu Sosial Program Studi Sosiologi Kekhususan Kesejah-teraan Sosial). Universitas Indonesia, Depok.

Tang, M. (2004). Loneliss: The perspectives of elderly people. Diperoleh dari http://proquest.umi. compqdweb index $=2 \&$ did $=918948711 \&$ Srch Mode $=1 \&$ sid $=1 \&$ Fmt $=6 \&$ VInst $=$ PROD $\&$ VType $=\mathrm{PQD} \& \mathrm{RQT}=309 \& \mathrm{VName}=\mathrm{PQD} \& \mathrm{TS}=127875$ 6423 \& clientId $=45625$.

Watson, R. (2003). Perawatan pada lansia. Jakarta: EGC. 